\title{
Tax Buoyancy in the Caribbean: Evidence from Heterogenous Panel Cointegration Models
}

\author{
Jeetendra Khadan ${ }^{1, *}$ \\ ${ }^{1}$ Inter-American Development Bank, Washington DC, U.S.A. \\ *Corresponding author: Inter-American Development Bank, Washington DC, U.S.A. E-mail: \\ jeetendra.khadan@gmail.com
}

Received: October 12, 2019 Accepted: December 10, 2019 Published: December 20, 2019

doi: 10.5296/rae.v11i4.15612ＵRL: https://doi.org/10.5296/rae.v11i4.15612

\begin{abstract}
This paper provides long and short run tax buoyancy estimates for a group of 12 Caribbean countries over the period 1991-2017. By using various panel regressions estimated by the Mean Group and Pooled Mean Group estimators, this paper finds that the long and short run tax buoyancy estimates are statistically greater than one. However, the results vary by tax categories: with respect to indirect taxes - which accounts for almost 65 percent of total tax revenues - the buoyancy of the long run coefficient significantly less than one (0.35), while for direct taxes it is significantly higher than one (1.33). It was also found that long run tax buoyancy was lower in the post global financial crisis period. With respect to short-run buoyancy, corporate taxes and trade taxes are the most buoyant in the short-run while property taxes were found to be statistically insignificant. For taxes on goods on services, the single most important tax for most countries, both long and short run buoyancy is not significantly different from one.
\end{abstract}

Keywords: fiscal sustainability, tax buoyancy, panel cointegration, error correction model, pooled mean group

JEL: E62, H21, H29, H68 


\section{Introduction}

Many Caribbean countries are facing fiscal and debt challenges. In the aftermath of the global financial crisis and recent commodity related shocks of 2015, economic growth contracted, and fiscal deficits and debt levels significantly increased. Real GDP growth has returned although it is still lower than the pre-crisis level, but fiscal imbalances and high debt levels continue to present challenges for some countries. Recent evidence from an intertemporal budget constraint and fiscal reaction functions also suggest that fiscal sustainability in the region has been "weak" (Khadan, 2019). Some countries are undertaking reform programs with the support of the International Monetary Fund (for example Barbados and Jamaica), while others such as Suriname and Trinidad and Tobago are pursuing home-grown reform programs to address their respective macroeconomic challenges. Those reform programs not only aim to support fiscal sustainability but also promote economic growth. Indeed, the International Monetary Fund has projected that the region's real GDP growth would increase to an average of 4.02 percent in the next 5 years compared to 1.47 percent in the previous 5 years. This raises the following question, to what extent could higher economic growth help reduce fiscal deficits in the Caribbean? From the revenue side of the budget, the answer depends on the buoyancy of the tax system.

Tax buoyancy measures how tax revenue changes with the level of GDP: a tax buoyancy estimate of one (1) indicates that a one percentage point increase in GDP would leave the taxto-GDP ratio unchanged, but a tax buoyancy estimate exceeding one would increase tax revenues by more than GDP which could potentially lower fiscal deficits and help put public finances on a sustainable path over the long-run (see Deli et al., 2018). Alternatively, if the change in GDP is negative, then a tax buoyancy larger than one would imply a deterioration of tax-to-GDP ratio.(note 1) Tax buoyancies can differ by tax type and over the short-run and long-run: short-run buoyancies give insights into the stabilization function of fiscal policy while long-run buoyancies are more important for long-term fiscal sustainability considerations. The tax system is said to be a good automatic stabilizer if the short-run buoyancy exceeds one, while a long-run buoyancy greater than one implies that higher economic growth can improve the fiscal balance through the revenue side of the budget.

In that context, the main contribution of this paper is twofold (i) estimating both short and longrun tax buoyancies for total tax revenues and 5 categories of tax revenues for a panel of Caribbean countries; (ii) analyzing short and long-run tax buoyancies for periods before and after the 2008 global financial crisis.(note 2) Previous studies of tax buoyancy in the Caribbean include Mitchell and Andrews (1999); Hamlet (2013) on a few Eastern Caribbean countries; Milwood (2011) on Jamaica and Cotton (2012) on Trinidad and Tobago. This paper is different from those as it considers a broader sample of Caribbean countries, accounting for the economic cycle and uses recent advances panel data econometrics. In that regard, this research adds to the growing body of work on tax buoyancy but from a developing country perspective and would provide useful empirical insights as regards long run fiscal sustainability and the extent to which taxes are an effective stabilization tool for smoothing the effects of the economic cycle in the Caribbean region.(note 3) The rest of this paper is organized as follows. Section 2 discusses the econometric specification and data. Section 3 outlines the estimation 
strategy and results of the econometric tests. Section 4 elaborates on the panel regression results and performs robustness checks. Finally, section 5 concludes the paper.

\section{The Econometric Model and Data}

This section outlines the econometric specification to estimate tax buoyancy following the works of Dudine and Jalles (2017) and Deli et al. (2018). The econometric specification is based on the following panel autoregressive distributive lag model $(p, q)$ :

$$
\ln T_{i, t}=\sum_{j=1}^{p} \emptyset_{i, j} \ln T_{i, t-j}+\sum_{j=0}^{q} \varphi_{i, j} \ln Y_{i, t-j}+\mu_{i}+\epsilon_{i, t}
$$

Where $T_{i, t}$ refers to total tax revenue or the relevant category of tax for country $i$ at time $t$, $Y_{i, t}$ denotes the GDP at time $t$ for country $i$, and $\mu_{i}$ represents the country fixed effects, and $\epsilon_{i, t}$ is the error term.

Following Deli et al. (2018) and subtracting the lagged tax variable from both sides of equation (1), the model specification is transformed into the following single error correction model (ECM):

$$
\Delta \ln T_{i, t}=\lambda_{i}\left(\ln T_{i, t-1}-\beta_{i} \ln Y_{i, t-1}\right)+\theta_{i, 0} \Delta \ln Y_{i, t} \mu_{i}+\epsilon_{i t}
$$

Where $\lambda_{i}=-\left(1-\emptyset_{i, 1}\right), \beta_{i}=\frac{\theta_{i, 0}+\theta_{i, 1}}{1-\emptyset_{i, 1}}, \lambda_{i}$ measures the country-specific speed of adjustment, that is how fast buoyancy converges to its long-run equilibrium. $\beta_{i}$ denotes the long run buoyancy and $\theta_{i, 0}$ measures the short run tax buoyancies. To obtain estimates for these parameters, equation 2 is estimated by Mean Group (MG) and Pooled Mean Group (PMG) estimators.

\subsection{Data}

The analysis covers 12 Caribbean countries using an unbalanced panel of annual data for the period 1991 to 2017. The countries included in the panel are Antigua and Barbuda, The Bahamas, Barbados, Dominica, Grenada, Guyana, Jamaica, Saint Lucia, St. Kitts and Nevis, Suriname, St. Vincent and the Grenadines and Trinidad and Tobago. Tax data is primarily obtained from two sources: The Economic Commission for Latin America and the Caribbean and the International Centre for Tax and Development/United Nations University-World Institute for Development Economics Research, Government Revenue Dataset 2018. The available data vary by country especially for certain tax categories for the period prior to 2000 . The analysis covers total tax revenues (TTR) and categories of tax revenues for direct taxes (DT), indirect taxes (IT), personal income taxes (PIT), corporate income taxes (CIT), taxes on goods and services (TGS), property taxes (PT) and trade taxes (TT). Table 1 shows the composition of tax revenues as a percent of GDP. Other variables such as inflation and GDP are taken from the International Monetary Fund, World Economic Outlook, April 2019. 
Table 1. Tax Revenue Components (\% of GDP) Average for 2008-2017

\begin{tabular}{lcccccccccc}
\hline & & & & & \multicolumn{3}{c}{ Direct taxes } & \multicolumn{2}{c}{ Indirect taxes } \\
\cline { 7 - 10 } & & TTR & DT & IT & SCOT & PIT & CIT & PT & TGS & TT \\
\hline ATG & 17.36 & 2.96 & 13.34 & 1.06 & 0.99 & 1.45 & 0.52 & 7.84 & 5.50 \\
BHS & 14.38 & 0.91 & 9.76 & 3.71 & & & 0.91 & 4.13 & 3.58 \\
BRB & 24.58 & 8.95 & 14.63 & 1.00 & 4.38 & 2.92 & 1.57 & 10.40 & 2.24 \\
DMA & 23.09 & 4.89 & 18.17 & 0.03 & 2.39 & 2.07 & 0.59 & 11.98 & 4.83 \\
GRD & 19.54 & 4.68 & 14.62 & 0.24 & 1.53 & 2.31 & 0.84 & 7.71 & 6.04 \\
GUY & 21.26 & 8.58 & 12.68 & 0.00 & 3.02 & 5.13 & 0.40 & 5.72 & 1.90 \\
JAM & 24.14 & 9.71 & 14.33 & 0.09 & 4.75 & 2.57 & 0.00 & 7.63 & 1.90 \\
KNA & 18.71 & 5.30 & 11.91 & 1.50 & 1.80 & 2.60 & 0.55 & 6.50 & 4.84 \\
LCA & 20.26 & 5.94 & 13.89 & 0.43 & 2.28 & 2.21 & 0.16 & 6.38 & 6.40 \\
SUR & 16.49 & 7.77 & 8.72 & 0.00 & 3.48 & 3.83 & 0.02 & 3.56 & 2.32 \\
TTO & 25.09 & 18.45 & 6.47 & 0.17 & 3.78 & 13.99 & 0.02 & 4.18 & 1.56 \\
VCT & 22.95 & 7.34 & 15.61 & 0.00 & 3.52 & 2.30 & 0.89 & 7.09 & 4.07 \\
\hline
\end{tabular}

Sources: Author's compilation from Economic Commission for Latin America and the Caribbean and the ICTD/UNU-WIDER.

Note: SCOT refers to social contributions and other taxes not specified.

\section{Estimations Strategy}

The approach used to estimate tax buoyancies involve four steps: (i) testing for cross sectional independence among panel units, (ii) testing for unit roots of each variable, (iii) testing for cointegration between the two variables and (iv) estimation of the panel cointegrating vector. The results of these tests are summarized below.

An important first step in deciding on the estimation procedure is to determine whether the variables are stationary in the mean by testing each variable for unit roots. However, with respect to panel data one must first test for cross-sectional dependence among panel units. If present, the so-called second generation panel unit root test of Pesaran (2007) which accounts for cross-sectional dependence across panel units should be used instead of the first generation tests (see for example Banerjee et al., 2004; 2005; Hurlin an Migon, 2007; Lyhagen, 2000; Phillips and Sul, 2003). In this regard, the Pesaran (2004) cross sectional dependence (CD) test which tests a null hypothesis of cross-section independence is applied to each variable. The results of the $C D$ test suggest a strong rejection of the null hypothesis indicating the presence of cross-sectional dependence-this is also evident from the relatively high correlation values (pij) for each variable in Table 2 . Hence, the evidence suggests the presence of cross-sectional dependence among the panel units. 
Table 2. Pesaran (2004) Tests for Cross Section Independence

\begin{tabular}{lccc}
\hline Variables (in logarithms) & CD-test & P-value & Avg. $|(\mathrm{pij})|$ \\
\hline Real GDP & 38.900 & 0.000 & 0.930 \\
Real tax revenues & 31.830 & 0.000 & 0.761 \\
Real direct tax revenues & 25.020 & 0.000 & 0.599 \\
Real indirect tax revenues & 30.290 & 0.000 & 0.724 \\
\hline
\end{tabular}

Source: Author's estimates.

The results of the panel unit root test are shown in Table 3. The Pesaran (2007) cross-sectionally augmented IPS (CIPS) test is based on the average of individual cross-sectionally ADF (CADF) statistic following Im, Pesaran and Shin (2003) and tests a null hypothesis of non-stationarity. It augments the standard Augmented Dickey Fuller (ADF) regressions with the cross-sectional average of lagged levels and first differences as the common factor to filter out the crosssectional dependence (see Pesaran, 2007). It has also been shown to have satisfactory size and power even when the dimensions of $\mathrm{N}$ and $\mathrm{T}$ are small-as in our case. The CIPS test is undertaken for all variables with constant and trend deterministics and a maximum of 5 lags for the panel units in the model. The critical values of the CIPS test with constant and trend are $-2.9(1 \%),-2.7(5 \%)$ and $-2.6(10 \%)$. The results of the CIPS test show that the tax variables and GDP are non-stationary in levels at the 5 and 10 percent level of statistical significance. However, applying the CIPS test to the first difference of the variables leads to a rejection of the null hypothesis of non-stationarity at all levels of statistical significance, implying that the variables are integrated to the order of one (see Table 3 ).

Table 3. Panel Unit Root Test

\begin{tabular}{lcc}
\hline & Pesaran (2007) (z-stat) & \\
Variables (in logarithms) & Levels & First differences \\
\hline Real GDP & -1.880 & -4.355 \\
Real tax revenues & -2.362 & -4.654 \\
Real direct tax revenues & -2.838 & -4.882 \\
Real indirect tax revenues & -2.684 & -4.903 \\
\hline
\end{tabular}

Source: Authors' calculations.

Notes: The critical value for the Pesaran (2007) test with constant and trend is -2.69 (5\%).

Now, the panel cointegration test of Westerlund (2007) is applied to determine if there is a longrun equilibrium relationship between GDP and each category of tax revenues. The Westerlund test statistics tests a null hypothesis of no cointegration and has several advantages including the use of bootstrapping to treat with cross-sectional dependence. There are four panel cointegration tests proposed by Westerlund that consists of two sets of alternative hypotheses: (i) group mean tests ( $\mathrm{Gt}$ and $\mathrm{Ga}$ ) and (ii) panel tests (Pt and $\mathrm{Pa}$ ). The main difference between the two sets of alternative hypotheses is based on how they treat with the equality of the error- 
correction term across panel units: the group mean tests do not assume equality of the errorcorrection while the panel tests assume that the error-correction term is equal for all panel units. The results show that, expect for one of the group mean test $(\mathrm{Ga})$ for direct tax revenues and indirect tax revenues, and both group mean tests for total tax revenue, there is strong evidence of cointegration between real GDP and each tax type in Table 4.(note 4) These results are sufficient to conclude that the null hypothesis of no-cointegration can be rejected.

Table 4. Westerlund ECM Panel Cointegration Tests

\begin{tabular}{|c|c|c|c|c|c|c|c|c|c|}
\hline & \multicolumn{3}{|c|}{ Tax revenue } & \multicolumn{3}{|c|}{ Direct tax revenues } & \multicolumn{3}{|c|}{ Indirect tax revenues } \\
\hline & Value & $\begin{array}{c}\mathrm{Z}- \\
\text { value }\end{array}$ & $\begin{array}{l}\text { Robust } \\
\text { P-value }\end{array}$ & Value & $\begin{array}{c}\mathrm{Z}- \\
\text { value }\end{array}$ & $\begin{array}{c}\text { Robust } \\
\text { P- } \\
\text { value }\end{array}$ & Value & $\begin{array}{c}\mathrm{Z} \text { - } \\
\text { value }\end{array}$ & $\begin{array}{c}\text { Robust } \\
\text { P- } \\
\text { value }\end{array}$ \\
\hline Gt & $1 . \overline{212}$ & -0.784 & 0.120 & $\begin{array}{c}- \\
1.562\end{array}$ & -1.951 & 0.030 & $\begin{array}{c}- \\
1.562\end{array}$ & -1.951 & 0.040 \\
\hline $\mathrm{Ga}$ & $\begin{array}{c}- \\
1.559\end{array}$ & 1.709 & 0.830 & $\begin{array}{c}- \\
2.053\end{array}$ & 1.333 & 0.700 & 2.053 & 1.333 & 0.760 \\
\hline $\mathrm{Pt}$ & $\begin{array}{c}- \\
18.11\end{array}$ & -14.00 & 0.000 & $\begin{array}{c}- \\
20.52\end{array}$ & -16.07 & 0.000 & $\begin{array}{c}- \\
20.52\end{array}$ & -16.07 & 0.000 \\
\hline $\mathrm{Pa}$ & $\begin{array}{c}- \\
6.221\end{array}$ & -6.216 & 0.000 & $\begin{array}{c}- \\
6.766\end{array}$ & -6.868 & 0.010 & $\begin{array}{c}- \\
6.766\end{array}$ & -6.868 & 0.000 \\
\hline
\end{tabular}

Source: Author's estimates.

Note: 400 bootstrap replications are used for to obtain Robust P-value in the Westerlund cointegration tests. The bootstrapped versions of the error-correction tests are robust to the presence of cross-sectional dependence.

\section{Panel Regression Results}

\subsection{Buoyancy of Total Tax Revenues}

Table 5 shows the results of panel regressions based on the MG and the PMG estimators using total tax revenues. The MG estimator of Pesaran and Smith (1995) estimates separate regressions for each unit in the panel and then computes a simple arithmetic average of the country-specific long run coefficients. Alternatively, the PMG estimator of Pesaran, Shin and Smith $(1997,1999)$ involves a combination of pooling and averaging of coefficients. The PMG estimator assumes that the long-run coefficients are homogeneous across panel units, while the other parameters (short run coefficients, the intercepts and error variances) are allowed to be heterogeneous across panel units (see Pesaran, Shin, and Smith, 1997, 1999; Samargandi, Fidrmuc, and Ghosh, 2015). A Hausman test is typically used to determine whether the homogeneity assumption of the long-run parameters hold. It tests a null hypothesis that the difference between the PMG and MG estimation is not systematic. Table 5 shows that the Hausman test fails to reject the null hypothesis indicating that the PMG estimator is more efficient under the null hypothesis than the MG estimator. Thus, we rely on the PMG estimator for our estimation results.

The long run and short run buoyancy coefficients, and the speed of adjustment parameters are 
found to have the expected signs and are statistically significant at all conventional levels of statistical significance. The speed of adjustment parameter under the PMG is -0.313 which is consistent with convergence to a long run relationship. It indicates that the system corrects any deviations in the previous period at a speed of 31.3 percent annually to revert to steady state. The size of the speed of adjustment coefficient is similar to previous studies, where the range was estimated as -0.236 for advanced countries to -0.339 for emerging economies (see Dudine and Jalles, 2017). The estimated long run (1.318) and short run (1.476) buoyancies are found to be statistically larger than one. On average, this may indicate that the tax system is a good automatic stabilizer - that is during periods of economic expansion tax receipts increases (money is taken out of the economy) while the reverse is true during periods of economic contraction-and can potentially improve long-run fiscal sustainability. However, tax buoyancy may change over the business cycle and can differ by tax revenue components which can alter these generalized interpretations.

Table 5. Tax Buoyancy for Total Tax Revenues

\begin{tabular}{lcc}
\hline & PMG & MG \\
\hline Long run buoyancy & 1.318 & 1.387 \\
& {$[0.048]^{* * *}$} & {$[0.204]^{* * *}$} \\
Short run buoyancy & 1.476 & 1.492 \\
& {$[0.447]^{* * *}$} & {$[0.503]^{* * *}$} \\
Speed of adjustment & -0.313 & -0.352 \\
& {$[0.050]^{* * *}$} & {$[0.051]^{* * *}$} \\
Constant & -2.83 & -3.757 \\
& {$[0.472]^{* * *}$} & {$[0.730]^{* * *}$} \\
Observations & 309 & 309 \\
Countries & 12 & 12 \\
Hausman test (MG vs. PMG) chi2(1) & 0.12 & \\
Prob>chi ${ }^{2}$ & {$[0.734]$} & \\
\hline
\end{tabular}

Estimations by PMG estimator. Standard errors in parenthesis, ${ }^{* *}$ Statistically significant at the $1 \%$ level. ${ }^{*}$ Statistically significant at the $5 \%$ level. * Statistically significant at the $10 \%$ level.

\subsection{Buoyancy over Pre-Crisis and Post-Crisis Periods}

The interest here is to examine tax buoyancies before and after the 2008 global financial crisis. In this regard and given the available data, the pre-crisis period is defined as 1991-2007 while the post-crisis period is from 2008-2017. The post-crisis period is characterized by relatively lower economic growth, higher fiscal deficits and lower tax revenues (see Table 6 below). 
Table 6. Economic Growth, Fiscal and Tax Revenue Performance

\begin{tabular}{|c|c|c|c|c|c|c|}
\hline & \multicolumn{2}{|c|}{$\begin{array}{c}\text { Real GDP growth } \\
(\%)\end{array}$} & \multicolumn{2}{|c|}{$\begin{array}{l}\text { Fiscal balance } \\
(\% \text { of GDP })\end{array}$} & \multicolumn{2}{|c|}{$\begin{array}{l}\text { Tax revenues } \\
(\% \text { of GDP })\end{array}$} \\
\hline & 1991-2007 & 2008-2017 & 1991-2007 & $2008-2017$ & 1991-2007 & $2008-2017$ \\
\hline ATG & 4.38 & -0.09 & -4.56 & -3.93 & 17.4 & 15.7 \\
\hline BHS & 2.19 & -0.10 & -1.31 & -3.77 & 14.4 & 11.1 \\
\hline BRB & 1.53 & -0.42 & 0.99 & -7.39 & 24.6 & 25.1 \\
\hline DMA & 2.27 & 0.39 & -2.66 & 0.63 & 23.1 & 19.9 \\
\hline GRD & 3.62 & 1.84 & -3.64 & -3.18 & 19.5 & 18.2 \\
\hline GUY & 3.77 & 3.76 & -4.43 & -3.60 & 21.3 & 19.5 \\
\hline JAM & 1.27 & -0.09 & -2.55 & -3.59 & 24.1 & 21.8 \\
\hline KNA & 4.07 & 1.99 & -3.85 & 2.53 & 18.7 & 17.6 \\
\hline LCA & 2.35 & 1.35 & -1.63 & -3.69 & 20.3 & 18.8 \\
\hline VCT & 3.74 & 0.18 & -1.83 & -2.45 & 22.9 & 20.5 \\
\hline SUR & 2.91 & 1.68 & -2.10 & -5.05 & 16.5 & 14.9 \\
\hline TTO & 6.71 & -0.45 & 0.59 & -4.00 & 25.1 & 22.5 \\
\hline
\end{tabular}

Sources: Author's estimates from the World Economic Outlook, April 2019; Economic Commission for Latin America and the Caribbean database and the ICTD/UNU-WIDER, 'Government Revenue Dataset', 2018

Table 7. Tax Buoyancy for Total Tax Revenues

\begin{tabular}{lcc}
\hline & Alternative Time Periods & \\
\hline & $1991-2007$ & $2008-2017$ \\
Long run buoyancy & 1.552 & 0.631 \\
Short run buoyancy & {$[0.145]^{* * *}$} & {$[0.136]^{* * *}$} \\
& 0.921 & 1.439 \\
Speed of adjustment & {$[0.680]$} & {$[0.118]^{* *}$} \\
& -0.419 & -0.236 \\
Constant & {$[0.057]^{* * *}$} & {$[0.051]^{* *}$} \\
& -5.275 & -0.783 \\
Observations & {$[0.781]^{* * *}$} & {$[0.376]^{* *}$} \\
Countries & 189 & 108 \\
\hline
\end{tabular}

Estimations by PMG estimator. Standard errors in parenthesis, *** Statistically significant at the $1 \%$ level. ** Statistically significant at the $5 \%$ level. * Statistically significant at the $10 \%$ level.

Table 7 shows the results of tax buoyancies for total tax revenues for two time periods. The 
error correction term is negative and statistically significant over both periods, also indicating convergence to a long run relationship. However, the speed of adjustment coefficient is almost two times lower in the post-crisis period (23.6 percent) compared to the pre-crisis period (41.9 percent). Notably, the long run buoyancy is higher in the pre-crisis period (1.55) compared to the post-crisis period (0.63) while in the post crisis period the short run buoyancy was significantly greater than one (1.439). Two inferences can be drawn from these findings: first is that it appears that the stabilization function of the tax system has become more effective in the post-crisis period, however, the long run fiscal sustainability function has weakened.

\subsection{Buoyancy of Tax Revenues Components}

Now we turn to estimating tax buoyancies for direct and indirect taxes and each of the 5 tax categories-PIT, CIT, TGS, PT and TT. In general, one would expect long run buoyancies to be larger (greater than one) for progressive taxes than for regressive taxes such as value added tax (VAT). However, the long-run buoyancy of TGS or VAT for example can exceed one if luxury items are mostly subject to standard VAT rates and necessities or goods with an income elasticity of less than one is subject to reduced VAT rates (Belinga, Benedek, de Mooij and Norregaard, 2004). Additionally, if economic growth occurs along with a fall in labour-income share then there can be an increase in the buoyancy of CIT. As taxes are generally good automatic stabilizers, one would expect short-run buoyancy coefficients for CIT to be relatively high. On the other hand, short-run buoyancy for PT is expected to be small as governments usually adjust PT rates counter-cyclically to stabilize its revenue (Norregaard, 2013). Short-run buoyancy for PIT might also be below one if countries have rigid wages and labor laws. Similarly, the short-run buoyancy for TGS can be less than one as consumers may tend to smooth consumption in response to business cycle fluctuations. The short-term buoyancies can also be affected by the level of tax compliance in countries, for example during a recession when taxpayers are credit constrained, compliance may fall leading to a decline in revenue by more than income.

Overall the results in Table 8 are in line with theoretical expectations. The long-run buoyancy for total direct taxes is statistically significant and above one (1.328) while for total indirect taxes it is found to be statistically significant and below one at 0.351 . These results indicate a progressive effect for direct taxes and a regressive effect for indirect taxes as expected a priori. Specifically, long-run buoyancy is found to exceed one for CIT (1.550) and PT (1.909), while it is below one for PIT (0.202), TGS (0.712) and TT (0.638). Short-run buoyancies for both direct and indirect taxes are statistically significant and above one: 1.225 and 1.390 respectively. However, short run buoyancy is higher than one for CIT (2.572), TGS (1.057) and TT (1.720) but is below one for PIT (0.720) and statistically insignificant for PT. The short run buoyancies indicate that CIT is the best automatic stabilizer while PT has the highest long run buoyancy coefficient. It is important to also note that although CIT has a high short run buoyancy it's share in total tax revenues for most countries is relatively low (averaging 15 percent). Trinidad and Tobago is the only outlier where CIT contributed to more than 50 percent of total tax revenues. Similarly, although PT has the largest long-run buoyancy coefficient its share in total taxes is relatively low (2.7 percent of total tax revenue on average). Despite overall tax revenues having high long and short run buoyancies, the results from the components of tax revenues indicate that for IT, which account for majority of tax revenues, the long-run buoyancy is less than one (0.351), where DT it is higher than one (1.328). How does tax buoyancy for Caribbean countries compare with other regions? Both long and short run tax buoyancies for the Caribbean are higher than those found for advanced and emerging countries, but somewhat similar to low income countries (see Dudine and Jalles, 2017 and Belinga, 
Benedek, de Mooij and Norregaard, 2004)

Table 8. Tax Buoyancy by Tax Revenue Components

\begin{tabular}{lccccccc}
\hline & & & \multicolumn{3}{c}{ DT } & \multicolumn{3}{c}{ IT } \\
\cline { 5 - 8 } & DT & IT & PIT & CIT & PT & TGS & TT \\
\hline Long run & 1.328 & 0.351 & 0.202 & 1.550 & 1.909 & 0.712 & 0.638 \\
buoyancy & {$[0.067]^{* * *}$} & {$[0.106]^{* * *}$} & {$[0.067]^{* * *}$} & {$[0.159]^{* * *}$} & {$[0.173]^{* * *}$} & {$[0.083]^{* * *}$} & {$[0.118]^{* * *}$} \\
Short run buoyancy & 1.225 & 1.390 & 0.720 & 2.572 & -0.398 & 1.057 & 1.720 \\
& {$[0.533]^{* *}$} & {$[0.385]^{* * *}$} & {$[0.332]^{* *}$} & {$[1.151]^{* *}$} & {$[0.773]$} & {$[0.613]^{*}$} & {$[0.296]^{* * *}$} \\
Speed of adjustment & -0.316 & -0.131 & -0.241 & -0.356 & -0.380 & -0.412 & -0.188 \\
& {$[0.054]^{* * *}$} & {$[0.038]^{* * *}$} & {$[0.065]^{* * *}$} & {$[0.062]^{* * *}$} & {$[0.099]^{* * *}$} & {$[0.082]^{* * *}$} & {$[0.061]^{* * *}$} \\
Constant & -3.184 & -0.041 & -0.061 & -4.671 & -7.469 & -1.828 & -0.861 \\
& {$[0.565]^{* * *}$} & {$[0.062]$} & {$[0.216]$} & {$[0.814]^{* * *}$} & {$[2.186]^{* * *}$} & {$[0.359]^{* * *}$} & {$[0.298]^{* * *}$} \\
Observations & 309 & 309 & 250 & 260 & 278 & 238 & 279 \\
Countries & 12 & 12 & 11 & 11 & 12 & 11 & 12 \\
\hline
\end{tabular}

Estimations by PMG estimator. Standard errors in parenthesis, *** Statistically significant at the $1 \%$ level. ** Statistically significant at the $5 \%$ level. * Statistically significant at the $10 \%$ level.

\subsection{Controlling for Inflation}

Table 9. Robustness Checks: Tax Buoyancy for Total Tax Revenues with and without Controlling for Inflation

\begin{tabular}{lcc}
\hline & No control for inflation & Control for inflation \\
\hline Long run buoyancy & 1.096 & 1.211 \\
& {$[0.010]^{* * *}$} & {$[0.032]^{* * *}$} \\
Short run buoyancy & 0.589 & 0.501 \\
& {$[0.086]^{* * *}$} & {$[0.010]^{* * *}$} \\
Long run price effect & & -0.135 \\
Short run price effect & & {$[0.038]^{* * *}$} \\
Speed of adjustment & & 0.584 \\
& -0.451 & {$[0.191]^{* * *}$} \\
Constant & {$[0.078]^{* * *}$} & -0.352 \\
Observations & -1.152 & {$[0.075]^{* * *}$} \\
Countries & {$[0.219]^{* * *}$} & -1.486 \\
& 309 & {$[0.281]^{* * *}$} \\
\end{tabular}

Estimations by PMG estimator. Standard errors in parenthesis, ${ }^{* *}$ Statistically significant at the $1 \%$ level. ${ }^{* *}$ Statistically significant at the $5 \%$ level. * Statistically significant at the $10 \%$ level.

A further robustness check of the results examines whether tax buoyancy is independent or not 
from price changes. To this end, panel regression models are estimated using nominal changes total tax revenues and nominal GDP and including inflation as separate control variable. The results shown in Table 9 indicates that inflation enters with a significant negative coefficient in the long-run but with a significant positive coefficient in the short-run. More importantly, the coefficient for long-run buoyancy is smaller than before which indicates that tax buoyancy does not appear neutral with respect to inflation.

\section{Conclusion}

This paper estimated the long and short run tax buoyancies for a panel of 12 Caribbean countries over the period 1991-2017 using panel unit-root and cointegration tests that controls for cross-sectional dependence. The econometric tests were applied not only to aggregate tax revenues but also total direct taxes and total indirect taxes and their main components (PIT, CIT, PT, TGS and TT). Robustness checks were conducted by estimating the model over precrisis and post-crisis periods, controlling for price developments and by using alternative estimators.

The results showed that long run and short run tax buoyancies for total tax revenues exceed one for the full period (1991-2017) but differ over the pre-crisis and post-crisis periods. Longrun tax buoyancy in the pre-crisis period was larger than one but declined to below one in the post-crisis period. However, the short run tax buoyancy was statistically insignificant in precrisis period but became statistically significant with a tax buoyancy exceeding one. The components of the taxes also revealed different buoyancy estimates. Indirect taxes, which accounts for the majority of the tax revenues, showed long run tax buoyancies significantly less than one while long run buoyancies for direct taxes were significantly larger than one. A policy implication of these findings is that to avoid further deterioration of the fiscal stance, any increases in the expenditure to GDP ratio, that are not contributing to structural improvements of the economy, would need to be accompanied by reform measures to mobilize revenues. These results are applicable to other small developing countries that face similar fiscal and debt challenges.

\section{References}

Banerjee, A., Marcellino, M., \& Osbat, C. (2004). Some cautions on the use of panel methods for integrated series of macro-economic data. Econometrics Journal, 7, 322-340. https://doi.org/10.1111/j.1368-423X.2004.00133.X

Banerjee, A., Marcellino, M., \& Osbat, C. (2005). Testing for PPP: should we use panel methods? Empirical Economics, 30, 77-91. https://doi.org/10.1007/s00181-004-0222-8

Belinga, V., Dora, B., Mooij de, R. A., \& John N. (2014). Tax Buoyancy in OECD Countries. IMF Working Papers 14/110, International Monetary Fund. https://doi.org/10.5089/9781498305075.001

Cotton, J. (2012). The Buoyancy and Elasticity of Non-Oil Tax Revenues in Trinidad and Tobago (1990-2009). WP 06/2012, Central Bank of Trinidad and Tobago.

Deli, Y., Abian, G. R., Ilias, K., \& Petros, V. (2018). Dynamic tax revenue buoyancy estimates for a panel of OECD countries. ESRI Working Paper, No.592, The Economic and Social Research Institute (ESRI), Dublin. 
Dudine, P., \& Talles, J. T. (2017). How buoyant is the tax system? New evidence from a large heterogeneous panel. IMF Working Paper WP/17/4. https://doi.org/10.5089/9781475569797.001

Hamlet, K. K. J. (2013). Tax Buoyancy in the Eastern Caribbean Currency Union and the Implications for Fiscal Consolidation: A Study of the Commonwealth of Dominica, St. Lucia and Antigua and Barbuda. Working Paper, Caribbean Centre for Money and Finance.

Hurlin, C., \& Valérie, M. (2007). Second Generation Panel Unit Root Tests. Working Papers, HAL.

Khadan, J. (2019). Fiscal Sustainability in the Caribbean: An Econometric Analysis. Research in Applied Economics, 11(2), 2019. https://doi.org/10.5296/rae.v11i2.14697

Leuthold, J. H., \& N'Guessan, T. (1986). Tax Buoyancy vs. Elasticity in a Developing Economy. Urbana-Champaign: University of Illinois.

Lyhagen, J. (2008). Why Not Use Standard Panel Unit Root Test for Testing PPP. Economics Bulletin, 3(26), 1-11.

Milwood, T. (2011). Elasticity and Buoyancy of the Jamaican Tax System. Bank of Jamaica.

Mitchell, W., \& Andrews, L. (1999). Tax Buoyancies in Eastern Caribbean Central Bank Member Countries. Working Paper 1999-13, Central Bank of Barbados.

Mourre, G., \& Savina, P. (2015). Tax Revenue Elasticities Corrected for Policy Changes in the EU. CESifo Working Paper Series 5657, CESifo Group Munich.

Norregaard, J. (2013). Taxing Immovable Property: Revenue Potential and Implementation Challenges. IMF Working Paper WP/13/129. https://doi.org/10.5089/9781484369050.001

Pesaran, H., Shin, Y., \& Smith, R. (1999). Pooled mean group estimation of dynamic heterogeneous panels. Journal of the American Statistical Association, 94, 62-134. https://doi.org/10.1080/01621459.1999.10474156

Pesaran, M. H. (2007). A Simple Panel Unit Root Test in the Presence of Cross Section Dependence. Journal of Applied Econometrics, 22, 265-312. https://doi.org/10.1002/jae.951

Pesaran, M. H., \& Smith, R. (1995). Estimating long-run relationships from dynamic heterogeneous panels. Journal of Econometrics, 68(1), 79-113. https://doi.org/10.1016/0304-4076(94)01644-F

Pesaran, M., Shin, Y., \& Smith, R. (1997). Pooled Estimation of Long-run Relationships in Dynamic Heterogeneous Panels. Cambridge Working Papers in Economics, Faculty of Economics, University of Cambridge.

Phillips, P. C. B., \& Sul, D. (2003). Dynamic Panel Estimation and Homogeneity Testing under Cross Section Dependence. The Econometrics Journal, 6, 217-259. https://doi.org/10.1111/1368-423X.00108

Samargandi, N., Jan, F., \& Sugata, G. (2015). Is the Relationship Between Financial Development and Economic Growth Monotonic? Evidence from a Sample of MiddleIncome Countries. World Development, 68(C), 66-81. 
https://doi.org/10.1016/j.worlddev.2014.11.010

Westerlund, J. (2007). Testing for Error Correction in Panel Data. Oxford Bulletin of Economics and Statistics, 69, 709-748. https://doi.org/10.1111/j.1468-0084.2007.00477.x

\section{Notes}

Note 1. Tax buoyancy of a tax is classified as regressive (progressive) if the long-run buoyancy estimate is below (above) one, and a buoyancy estimate equal to one would leave the tax-toGDP ratio unchanged (see Mourre and Princen, 2015).

Note 2. This paper considers only tax buoyancy which measures the responsiveness of a tax system to changes in the relative tax base, inclusive of discretionary changes. But one can also estimate tax elasticity which measures the responsiveness of a tax system to changes in the relative tax base, exclusive of discretionary changes (see for example Cotton (2012) and Hamlet (2013) for studies on tax elasticity on selected countries in the Caribbean). The discretionary tax measures refer to changes in tax rates, tax bases, tax allowances and credits, and of administrative tax efficiency (Hassen, 2016). Obtaining accurate information on discretionary revenue changes often presents a challenge and even if available their inclusion can lead to significant loss of degrees of freedom, especially in developing countries with relatively short time series (see Leuthold and N'Guessan, 1986 for a discussion on tax buoyancy and tax elasticity in developing countries).

Note 3. For similar works on developed countries see for example Belinga, Benedek, de Mooij and Norregaard, 2004; Dudine and Jalles, 2017; Deli el at. 2018.

Note 4. It is important to note that Monte Carlo simulations has shown the panel tests to have the highest power among the two sets of alternative hypotheses, and Gt has the highest power among the group mean tests.

\section{Copyright Disclaimer}

Copyright for this article is retained by the author(s), with first publication rights granted to the journal.

This is an open-access article distributed under the terms and conditions of the Creative Commons Attribution license (http://creativecommons.org/licenses/by/3.0/). 